\title{
KEBANGKITAN STUDI TEOLOGI PATRISTIK: Doktrin Trinitas (Perikhoresis)
}

\author{
Minggus Minarto Pranoto*
}

\begin{abstract}
Abstrak: Teologi Patristik atau teologi bapa-bapa gereja muncul di masa-masa awal dalam sejarah perkembangan gereja. Namun demikian pemikiran teologi Patristik masih terus relevan berhadapan dengan persoalan-persoalan kehidupan sekarang ini. Teologi Patristik merupakan warisan berharga teologi Kristen yang tidak pernah membeku dan menjadi fosil di masa lalu, sebaliknya teologi Patristik mengalami kebangkitan dalam topik-topik kajiannya dan mempunyai daya dorong yang kuat untuk mendasari praksis transformasional pelayanan Kristen di masa sekarang ini. Kebangkitan studi teologi Patristik menunjukkan bahwa teologi Patristik memiliki ruang yang luas untuk diaplikasikan dalam berbagai isu kehidupan. Teologi Patristik setia terhadap kerygma rasul-rasul dan tujuannya agar kehidupan orang percaya memuliakan Allah dan berjuang melakukan praksis transformasional pelayanan Kristen. Doktrin Trinitas (perikhoresis), yang telah diformulasikan dalam teologi Patristik, merupakan salah satu doktrin yang begitu luas didiskusikan dan dikembangkan dalam wacana berteologi sekarang ini.
\end{abstract}

Abstract: Patristic theology or theology of the Church Fathers emerged in the early days in the history of the development of the Church. However, the thought of Patristic theology continues to be relevant in dealing with the problems of life today. Patristic theology is a valuable legacy of Christian theology that has never been frozen and fossilized in the past, instead Patristic theology experienced a revival in its study topics and has a strong impetus to underpin the transformational praxis of Christian service in the present. The revival of the study of Patristic theology shows that Patristic theology has ample scope to be applied in various issues

*Penulis adalah dosen tetap Sekolah Tinggi Teologi Abdiel Ungaran. Penulis dapat dihubungi melalui email: minggusminarto@gmail.com. 
of life. Patristic theology is faithful to the apostolic faith and its purpose so that the lives of believers glorify God and strive to carry out transformational praxis of Christian service. The doctrine of the Trinity (perikhoresis), which has been formulated in Patristic theology, is one of the doctrines that is so widely discussed and developed in current theological discourse.

Kata-kata Kunci: Kebangkitan teologi Patristik, bapa-bapa Gereja, praksis transformasional, Trinitas, perikhoresis

\section{Pengantar}

Teologi Patristik adalah teologi yang dihasilkan oleh bapa-bapa gereja di awal sejarah perkembangan gereja. Meskipun bapa-bapa gereja dari lima abad pertama memberikan kontribusi yang signifikan terhadap perkembangan doktrin Kristen, tetapi pemikiran bapa-bapa gereja selanjutnya, sesudah Konsili Nicea dan Kalsedon seperti Maximus Sang Pengaku, yang mengembangkan doktrin dua kehendak Kristus dan Yohanes dari Damaskus yang mengembangkan teologi lkon, tidak boleh diabaikan begitu saja terutama sumbangan pemikiran teologi keduanya terkait dengan doktrin Kristologi. Oleh karena itu penulis tidak sependapat dengan Alister McGrath, yang mengikuti formula Protestan atau Gereja Barat pada umumnya, membagi periodisasi bapa-bapa gereja berdasarkan periode abad I sampai V atau di empat Konsili pertama saja. ${ }^{1}$ Pembagian tersebut dalam tradisi Gereja Barat menempatkan hasil pemikiran teologi Konsili ekumenis Kalsedon sebagai puncaknya dan dengan demikian menjadikan hasil pemikiran

1. Lihat Alister E. McGrath, Historical Theology: An Introduction to the History of Christian Thought (Malden: Blackwell, 1998), 17. 
teologi dari konsili-konsili sesudahnya sebagai "appendix" saja. Sebaliknya formula Gereja Timur menempatkan tujuh konsili pertama di abad I-VIII sebagai acuan dasar spiritualitas dan pemikiran doktrin Kristen. Menurut Georges Florovsky, hendaknya dua batasan formula tersebut tidak dimaksudkan bahwa pemikiran-pemikiran teologi bapabapa Gereja menjadi terkurung dalam periode-periode masa lalu saja dan kemudian ini berakibat bahwa pemikiran otoritas normatif gereja dibatasi implikasi praksisnya. ${ }^{2}$ Florovsky menambahkan bahwa teologi bapa-bapa gereja seharusnya menjadi teologi yang tidak sekadar diulang-ulang (theology of repetition), sebaliknya teologi mereka tersebut mesti dikembangkan lebih lanjut. ${ }^{3}$ la memberi contoh misalnya di abad XIV perkembangan dinamis teologi Patristik dapat dilihat dalam Teologi Bizantium (Byzantine Theology), dengan salah satu tokohnya bernama Gregorius Palamas, ${ }^{4}$ yang teologinya membicarakan energienergi ilahi (divine energies) sebagai sebuah cara yang meyakinkan untuk memahami hubungan Allah dengan dunia. ${ }^{5}$

Hasil pemikiran bapa-bapa Gereja yang dirumuskan dalam berbagai Konsili telah menjadi dasar utama bagi pengajaran utama gereja-gereja baik di Timur dan Barat, seperti misalnya pengajaran mengenai dua tabiat Yesus Kristus, doktrin Trinitas, doktrin mengenai

2. George Florovsky, "St. Gregory Palamas and the Tradition of the Fathers" dalam The Collected Works of Georges Florovsky (Vaduz, Europa: Buchervertriebsanstalt, 1987), 111

3. Florovsky, "St. Gregory Palamas", 111.

4. Florovsky, "St. Gregory Palamas", 111.

5. David Bradshaw, "The Concept of The Divine Energies", dalam Philosophy \& Theology 18/1 (2000): 93. 
gereja, doktrin mengenai anugerah Allah, dan kredo Kristen. Mereka memformulasikan pemikiran-pemikiran dasar iman Kristen tersebut di atas melalui interaksi yang dinamis seperti mengontekstualisasikan iman Kristen dengan menggunakan pemikiran filsafat Yunani; melalui perlawanan terhadap pengajaran bidat-bidat; melalui pergulatan hidup mereka yang tidak terlepas keterkaitannya dengan masalah-masalah sosial politik dan kekuasaan, persekusi, kepentingan kelompokkelompok dan dinamika kehidupan Gereja yang melatarbelakanginya waktu itu. Bapa-bapa gereja telah menafsir dan mengembangkan kerygma rasul-rasul (Apostolik) ke dalam bentuk pengajaran utama iman Kristen. Florovsky berkata: "The Church is 'Apostolic' indeed. But the Church is also 'Patristic'. She is intrinsically 'the Church of the Fathers'. These two 'notes' cannot be separated. Only by being 'Patristic' is the Church truly 'Apostolic'". ${ }^{6}$ Relasi keduanya ini dapat disebut juga sebagai relasi antara Kitab Suci sebagai sumber utama dan tertinggi bagi kebenaran Kristen dan Tradisi sebagai cara-cara memberikan kepastian penafsiran dalam menyingkapkan makna kebenaran otentik Kitab Suci. ${ }^{7}$

Kebangkitan studi teologi Patristik dalam beberapa puluh tahun terakhir ini menunjukkan bahwa teologi tersebut bukanlah sebuah teologi yang "mati", sebaliknya teologi tersebut tetap relevan dalam berbagai konteks dan ikut berkontribusi dalam memberikan sumbangan pemikiran untuk menjawab berbagai pergumulan kehidupan yang

6. George Florovsky, "St. Gregory Palamas", 107.

7. George Florovsky, "The Function of the Tradition in the Ancient Church", dalam Eastern Orthodox Theology: A Contemporary Reader, peny. Daniel B. Clendenin (Grand Rapids: Baker Academic, 2003), 99. 
kompleks. Memang ada beberapa kritik yang menyoroti secara tajam bahwa teologi Patristik sangat dipengaruhi oleh kebudayaan dan cara berpikir patriarki dan berfokus pada kajian metafisika yang abstrak. Juga perlu diberi catatan bahwa tidak dipungkiri ada beberapa pengajaran dari para bapa Gereja yang diperdebatkan atau bahkan kebanyakan ditolak baik oleh Gereja Timur maupun Gereja Barat seperti misalnya pengajaran apokatastasis yang disinyalir berasal dari Origen dan pengajaran monergisme dari Agustinus. Namun demikian kedua pengajaran tersebut seperti doktrin apokatastasis disinyalir dikembangkan lagi oleh para teolog Neo-Ortodoks seperti Karl Barth ${ }^{8}$ dan doktrin monergisme masih berpengaruh dalam teologi Reformed yang menekankan kedaulatan Allah dalam keselamatan. ${ }^{9}$

Tulisan ini bertujuan untuk memaparkan bahwa pemikiran teologi Patristik masih terus relevan berhadapan dengan persoalanpersoalan kehidupan sekarang ini. Pernyataan tesis yang dibangun adalah: teologi Patristik merupakan warisan berharga teologi Kristen yang tidak pernah membeku dan menjadi fosil di masa lalu, ${ }^{10}$ tetapi sebaliknya teologi Patristik mengalami kebangkitan dalam topik-topik kajiannya dan mempunyai daya dorong yang kuat untuk mendasari praksis transformasional pelayanan Kristen di masa sekarang. Dalam

8. Roger E. Olson, The Story of Christian Theology: Twenty Centuries Tradition \& Reform (Downers Grove: InterVarsity Press, 1999), 586.

9. Olson, The Story of Christian Theology, 612.

10. Minggus M. Pranoto, Perikhoresis Sabda-Roh: Imajinasi "Dua Tangan Allah" untuk Kepemimpinan Feminis (Ungaran: STT Abdiel, 2018),10. 
tulisan ini, penulis secara khusus memberikan contoh mengenai doktrin Trinitas, perikhoresis.

\section{Warisan Berharga Teologi Kristen dari Bapa-Bapa Gereja}

Teologi Patristik atau teologi bapa-bapa Gereja meletakkan dasar pengajaran ortodoks yang signifikan dalam mempertahankan keotentikan pengajaran iman Kristen. Teologi Patristik tidak saja berbicara atau bersaksi mengenai "the old faith" (testes antiquitas) tetapi juga "the true faith" (testes veritatis) ${ }^{11}$ yang berlandaskan kebenaran Kitab Suci.

Sebutan bapa-bapa gereja sebenarnya mengacu kepada para teolog yang menjelaskan pokok-pokok pengajaran iman Kristen di awal sejarah gereja. Mereka ini disebut juga sebagai guru-guru dan pemimpin-pemimpin Kristen awal atau yang disebut bishop. ${ }^{12}$ Mereka adalah para pengajar yang cakap mengenai instruksi-instruksi iman Kristen dan katekisasi. Mereka meneruskan dan mentransmisikan pengajaran rasul-rasul. Dengan demikian arti terminologi bapa-bapa gereja, sebagaimana diartikan oleh Origen, adalah pengajar-pengajar yang berbicara atas nama gereja atau viri ecclesia (on behalf and in the name of the church). ${ }^{13}$ Hasil kesepakatan pengajaran bersama para bapa

11. Florovsky, "St. Gregory Palamas", 107.

12. George Florovsky, "The Authority of the Ancient Councils and the Tradition of the Fathers", dalam Eastern Orthodox Theology: A Contemporary Reader, peny. Daniel B. Clendenin (Grand Rapids: Baker Academic, 2003), 122.

13. Florovsky, "The Authority of the Ancient Councils", 123. 
gereja disebut oleh Vincent of Lérins sebagai magistri probabiles, atau yang terkait dengan,

... the sayings of the holy Fathers; but yet of those only who, in their time and place, were approved masters [magistri probabiles], being such as continued in the unity of the communion and faith; ... they held with one mind and one consent, to judge that without all scruples to be the true and chatolic doctrine of the Church. ${ }^{14}$

Para bapa Gereja adalah sebagai “ . . . spokesmen for the church, expositors of her faith, keepers of her tradition, witnesses of truth and faith". ${ }^{15}$ Mereka memberikan inspirasi di dalam keputusan-keputusan konsili-konsili. Misalnya dalam konteks keputusan Konsili di Nikea, George L. Prestige menegaskan bahwa:

The real intellectual work, the vital interpretative thought, was not contributed by the Councils that promulgated the creeds, but by the theological teachers who supplied and explained the formulae which the Council adopted. The teaching of Nicea, which finally commended itself, represented the views of intellectual giants working for a hundred years before and for fifty years after the actual meeting of the Council. ${ }^{16}$

Pengajaran bapa-bapa gereja disebut consensus patrum. ${ }^{17}$ Artinya pengajaran yang dimunculkan bukanlah oleh opini-opini privat

14. William Goode, Divine Rule of Faith and Practice, Vol. II (London: J. Hatchard and Son, 1842), 262.

15. Basilius Steidle, Patrologia (Freiburg, Germany, 1973), 9. Dikutip dalam Florovsky, "The Authority of the Ancient", 123.

16. George L. Prestige, Fathers and Heretics (New York: The Macmillan Company, 1940),8.

17. Florovsky, "The Authority of the Ancient Councils", 124. 
perorangan dari bapa-bapa Gereja, ${ }^{18}$ tetapi mereka bersama-sama merefleksikan "the mind of the catholic and universal church ( to $^{\circ}$

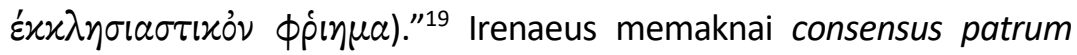
sebagai adanya keidentikan pengajaran bersama para bapa gereja mengenai pokok-pokok kepercayaan iman Kristen. Hal ini membuktikan juga bahwa pengajaran mereka memiliki "power of tradition". ${ }^{20}$ Kekuatan dari Tradisi bukan karena memiliki otoritas historis atau telah diputuskan dalam konsili-konsili semata-mata. Namun yang lebih penting yaitu memiliki otoritas kausatif, yaitu sumber atau penyebab munculnya Tradisi berasal dari tuntunan dan pimpinan Roh Kudus dan "bukanlah kesinambungan memori, atau ritus-ritus permanen dan kebiasaan-kebiasaan manusia". ${ }^{21}$ Roh Kudus Sang pemberi otoritas karismatik 22 menjadikan Tradisi Gereja sebagai Tradisi yang hidup yang berisi pengajaran iman Kristen yang terus dipercaya dan dipraktikkan atau menurut Irenaeus sebagai depositum juvenescens. ${ }^{23}$ Florovsky menambahkan bahwa:

Ultimately, tradition is a continuity of the abiding presence of the Holy Spirit in the Church, a continuity of the abiding presence of the Holy Spirit in the Church, a continuity of Divine guidance and illumination. The Church is not bound by the "letter".

18 Florovsky, "The Authority of the Ancient Councils", 124.

19 Florovsky, "The Authority of the Ancient Councils", 124.

20 Irenaeus, Adversus Omnes Haereses 1.10.2. Dikutip dalam Florovsky, "The Authority of the Ancient Councils", 124.

21 Florovsky, "St. Gregory Palamas", 106.

22 Lihat Florovsky, "The Authority of the Ancient Councils", 124.

23 Florovsky, "St. Gregory Palamas", 106. 
Rather, she is constantly moved forth by the "Spirit". The same Spirit, the Spirit of Truth, which "spoke through the Prophets", which guided the Apostles, is still continuously guiding the Church into the fuller comprehension and understanding of the Divine truth, from Glory to Glory". ${ }^{24}$

Teologi Patristik termasuk dalam kategori teologi ortodoks atau memiliki kebenaran pengajaran dalam teologinya (theological correctness). Teologi Patristik memberi kritik penting dan revisi kritis terhadap pengajaran bidat-bidat yang menyimpang dari pengajaran iman Kristen. Misalnya pengajaran tentang ke-llahian Yesus Kristus secara tepat dapat dipahami melalui perlawanan teologi dari para bapa gereja seperti Athanasius, Basil Agung, Gregorius dari Nyssa dan Gregorius dari Nazianzus terhadap pengajaran Arius dari Aleksandria. ${ }^{25}$ Arius menolak ke-llahian Yesus Kristus (juga Roh Kudus) yang bersama dengan Allah Bapa sejak kekekalan. Penolakan Arius antara lain didasari oleh kutipan ayat di Amsal 8:22 dan ayat-ayat dominan Kitab Suci lainnya seperti di Injil Yohanes 3:35; 10:30; 12:27; 14:10; 17:3, $11^{26}$ serta penekanan pada konsep homoiousios sebagai lawan terhadap pengajaran ortodoks Kristen mengenai konsep homoousios dari para bapa Gereja, yang menjelaskan bahwa Yesus memiliki substansi yang sama dengan Allah Bapa dan tidak sekadar mirip substansinya dengan Allah Bapa sebagaimana diartikulasikan oleh konsep yang pertama itu.

24. Florovsky, "St. Gregory Palamas", 106.

25. Olson, The Story of Christian Theology, 21.

26. Lihat Alister E. McGrath, Historical Theology, 49. 
Teologi Patristik menjadi "a definitive landmark" dalam perkembangan doktrin Kristen dan masih berpengaruh bagi gerejagereja arus utama sampai sekarang ini. ${ }^{27}$ Alister E. McGrath menegaskan:

The patristic period is one of the most exciting and creative periods in the history of Christian Thought. This feature alone is enough to ensure that it will continue to be the subject of study for many years to come. The period is also important for theological reasons. Every mainstream Christian bodyincluding the Anglican, Eastern Orthodox, Lutheran, Reformed and Roman Catholic churches-regards the patristic period as a definitive landmark in the development of Christian doctrine. Each of these churches regards themselves as continuing, extending and, where necessary, criticizing the views of the early church writers. ${ }^{28}$

Selanjutnya, teologi Patristik mempunyai kadar pengajaran yang sarat dengan prinsip nilai-nilai etika dan moral. Ini setidaknya dibuktikan melalui cukup banyaknya pemikiran teologi Patristik yang dipakai untuk mendukung dokumen-dokumen yang dihasilkan oleh Gereja Katolik dalam keputusan Vatikan II. Ambil contoh tentang perhatian yang serius terhadap persoalan-persoalan kemanusiaan seperti problem keadilan ${ }^{29}$ dan kemiskinan ${ }^{30}$ yang dimunculkan dalam teologi Patristik. Eksistensi

27. McGrath, Historical Theology, 17.

28. McGrath, Historical Theology, 17.

29. http://www.vatican.va/archive/hist_councils/ii_vatican_council/ documents/vat-iiconst19651207gaudium-et-spes_en.html. Diakses 17 Juli 2019. Dokumen ini memberikan pandangan mengenai keadilan dari pemikiran Irenaeus, dalam tulisannya Adversus haereses, V, 36, PG, VIII, 1221.

30. http://www.vatican.va/archive/hist_councils/ii_vatican council/ documents/vat-ii_const_19651207_gaudium-et-spes_en.html. Diakses 17 Juli 
manusia menjadi salah satu kajian yang penting dalam teologi Patristik karena dalam teologi tersebut terdapat keyakinan yang kuat bahwa Allah menyatakan kemuliaan-Nya dalam kehidupan manusia, yang dicipta menurut rupa dan gambar-Nya. Dalam perkembangan pemikiran teologi Kristen kontemporer, muncul juga usaha-usaha lainnya untuk membuat teologi Patristik terkait implikasinya dengan isu-isu kosmologi. ${ }^{31}$

\section{Praksis Transformasional Pelayanan Kristen (Implikasi Doktrin Trinitas, Perikhoresis)}

Agar teologi Patristik memiliki implikasi yang luas dan kebaruan baik dalam teori maupun dalam praksisnya teologi tersebut harus dikembangkan secara kreatif tetapi tanpa meninggalkan sikap kritis saat teologi tersebut bersintesis dengan isu-isu tertentu atau istilahnya disebut sintesis neo-Patristik. Pemikiran teologi Patristik yang diformulasikan dalam keputusan konsili-konsili bukanlah sebuah rumusan akhir atau solusi akhir tetapi justru merupakan awal permulaan refleksi yang segar dan baru serta kerangka berpikir untuk dikembangkan dalam diskursus teologis selanjutnya secara kreatif dan

2019. Dokumen ini memberikan acuan dalam soal kemiskinan dari pemikiran teolog Patristik seperti dari St. Basil, Hom. in illud Lucae "Destruam horrea mea," n. 2 (PG 31, 263);; St. Augustine, In loann. Ev. tr. 50, n. 6 (PL 35, 1760); St. Augustine, Enarratio in Ps. CXLVII, 12 (PL 37, 192). Diakses 17 Juli 2019.

31. Sebagai contoh lihat Torstein Tollefsen, The Christocentric Cosmology of St. Maximus the Confessor (Oxford \& New York: Oxford University Press, 2008) dan Hans Urs Von Balthasar, Cosmic Liturgy: The Universe According to Maximus the Confessor (San Francisco: A Communio Book, 2003). 
inovatif dalam kehidupan Kristen, terkait hubungan Allah, manusia dan seluruh ciptaan lainnya. ${ }^{32}$ Alexei Nesteruk menambahkan bahwa:

However, the return to the Fathers must be creative. This implies that 'one has to reassess both the problems and the answers of the Fathers' with an element of self-criticism. 'We must not only retain the experience of the Fathers, but moreover develop it while discovering it, and use it in order to create a living work..." 33

Sintesis neo-Patristik berarti juga merelevankan pemikiran teologi Patristik, yang tidak terpisah dari Kitab Suci, dan mengklaim bahwa teologi tersebut masih mempunyai daya pengaruh implikasinya dalam praksis transformasional pelayanan Kristen. Dengan demikian, teologi Patristik dapat termanifestasikan dalam eksistensi kehidupan Kristen dan memberikan orientasi spiritual terhadap praktik kehidupan saleh Kristen.

32. Lihat Catherine Mowry LaCugna, God for Us: The Trinity \& Christian Life (Chicago: HarperCollins, 1993), 5. Ambil contoh dalam konteks pengembangan lebih lanjut formula dogmatis Chalcedon, LaCugna mengatakan sebagai berikut: "Many theologians concluded that the dogmatic formulation of Chalcedon was not the end, not a finished solution, but only a beginning for fresh reflection on the question of who Jesus Christ is for contemporary men and women. Classical christological theories underwent radical interpretation in line with contemporary thought patterns and according to different philosophical and hermeneutic presuppositions, cultural contexts, and experiental priorities. The result has been a wide variety of christologies: kerygmatic-confessional, kenotic, liberationist, feminist, black, process, narrative, eschatological, and others" (h. 5).

33. Alexei Nesteruk, The Universe as Communion: Towards a NeoPatristic Synthesis of Theology and Science (London: T. \& T. Clark, 2008), 14. 
Patristic theology could be only preached or proclaimedpreached from the pulpit, proclaimed also the words of prayer and in the sacred rites, and indeed manifested in the total structure of Christian life. Theology of this kind can never be separated from the life of prayer and from the exercise of virtue. ${ }^{34}$

Contoh mengenai kebangkitan teologi Patristik dapat dibuktikan melalui salah satu pengembangan pengajaran utama yang dirumuskan oleh para bapa gereja, yaitu doktrin Trinitas (perikhoresis) dalam zaman sekarang ini terutama dalam konteks pelayanan praksis transformasional pelayanan Kristen. Penulis berbeda pendapat dari konsep pemikiran Immanuel Kant mengenai doktrin Trinitas. Kant berpendapat bahwa doktrin Trinitas tidak memiliki relevansi praktis sama sekali. Pendapat Kant sebagai berikut:

The doctrine of the Trinity, taken literally, has no practical relevance at all, even if we think we understand it; and it is even more clearly irrelevant if we realize that it transcends all our concepts. Whether we are to worship three or ten persons in the Divinity makes no difference: the pupil will implicitly accept one as readily as the other because he has no concept at all of a number of persons in one God (hypostases), and still more so because this distinction can make no difference in his rules of conduct. ${ }^{35}$

Kant menegaskan bahwa pengajaran mengenai Tiga Pribadi Trinitas tidak mempunyai makna apa pun. Misalnya terkait dengan pengajaran

34. Florovsky, "St. Gregory Palamas", 108.

35. Immanuel Kant, The Conflict of the Faculties, terj. Mary J. Gregor (New York: Abaris Books, 1979), 65-66. 
mengenai persekutuan Ilahi dan karya-karya bersama dari ketiga Pribadi (Allah Bapa, Putera, dan Roh Kudus) dalam penciptaan, keselamatan, dan penyempurnaan sebagaimana dipegang dan dipercaya oleh para bapa Gereja. Bagi Kant tidak dapat ditarik kesimpulan dari doktrin Trinitas (tiga Pribadi Allah atau pun bahkan sepuluh Pribadi) terkait dengan persekutuan llahi dan karya-karya di atas.

Kutipan pernyataan Kant di atas mungkin dapat dibenarkan jika pemahaman terhadap doktrin Trinitas hanya dipahami dalam batas garis-garis cakupan rasional belaka tanpa melibatkan tindakan iman yang dilandasi oleh pengetahuan dan pengalaman spiritual orang-orang percaya dengan Allah Trinitas. Namun demikian harus dimengerti bahwa doktrin Trinitas tidak dapat dijelaskan secara rasional sematamata. Mungkin dalam tingkatan penjelasan rasional tertentu doktrin tersebut dapat diterangkan secara terbatas misalnya melalui analogianalogi seperti relasi antara kesatuan benda matahari dengan sinar dan panasnya atau pun seperti kesatuan antara bunga, warna dan wanginya. Selebihnya itu melampaui rasionalitas manusia atau bersifat transrasional. Agustinus, bapa gereja dari Barat, telah membuat banyak analogi dibandingkan bapa-bapa gereja yang lain baik di Gereja Timur maupun di Gereja Barat dalam menjelaskan doktrin Trinitas. ${ }^{36}$ Meskipun demikian ia menyadari sepenuhnya bahwa ada keterbatasan absolut dari akal budi orang-orang percaya untuk memahami sepenuhnya tentang keberadaan Allah Trinitas.

36. Lihat LaCugna, God for Us, 81-110. 
Para teolog kontemporer telah mengkaji dan "menghidupkan" kembali doktrin Trinitas dan mendiskusikannya secara luas baik secara teoritis maupun implikasi praksisnya. Banyak pengajaran teori yang baru dalam ilmu teologi dan implikasi praksis transformasional pelayanan Kristen bermunculan didasarkan atas doktrin Trinitas. Dalam kenyataannya, doktrin tersebut dapat didialogkan secara luas dengan isu-isu dalam sosial politik, ekonomi, gender, ekologi, dialog agamaagama, dst. Catherine Mowry LaCugna menegaskan bahwa: "The doctrine of the Trinity is ultimately a practical doctrine with radical consequences for Christian life ${ }^{\prime \prime}{ }^{37}$ Doktrin Trinitas dapat menjadi fondasi yang subur dan sumber untuk setiap refleksi seluruh aspek kehidupan Kristen. ${ }^{38} \mathrm{Apa}$ yang dapat menjadikan demikian? Jawabnya karena doktrin Trinitas adalah doktrin yang sangat vital yang berbicara baik tentang kehidupan Allah sendiri maupun kehidupan Allah dalam relasinya dengan ciptaan-Nya, yang dalam bahasa LaCugna disebut keberadaan dan karya Trinitas Allah dalam pengertian oikonomia dan theologia untuk membedakan dan memperluas konsep ad intra dan ad extra yang digagas oleh Karl Rahner. ${ }^{39}$

Ambil contoh salah satu konsep teologi Patristik tentang Trinitas

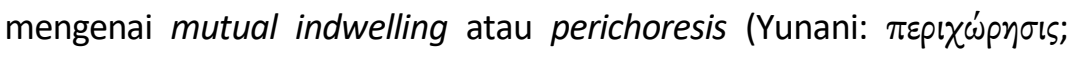
Indonesia: perikhoresis) ternyata begitu luas didiskusikan dan dikembangkan dalam wacana berteologi sekarang ini. Para pemikir

37. LaCugna, God for Us, 1.

38. LaCugna, God for Us, 2.

39. LaCugna, God for Us, 222-24. 
Kristen awal yang mengembangkan konsep ini antara lain: Gregorius dari Nazianzus, Pseudo-Cyrillus dari Aleksandria, Yohanes dari Damaskus dan Maximus Sang Pengaku. ${ }^{40}$ Meskipun secara eksplisit konsep ini tidak dituangkan dalam keputusan konsili-konsili awal dalam sejarah gereja dan secara kongkrit baru diformulasikan di Konsili Florence (1235-1345), tetapi ide gagasan dasar teologisnya jelas tampak dalam perumusan doktrin Kristologi dan Trinitas di awal sejarah gereja. Teolog masa kini seperti Jürgen Moltmann menyebut perikhoresis sebagai “An Old Magic Word for a New Trinitarian Theology" ${ }^{41}$ dan Michael G. Lawler mengistilahkannya sebagai "New Theological Wine in an Old Theological Wineskin". ${ }^{42}$ Kedua teolog ini menegaskan bahwa meskipun perikhoresis adalah konsep yang sudah tua namun memberi "new insight" bagi praksis transformasional pelayanan Kristen.

Secara teologis, kata perikhoresis menjelaskan mengenai persekutuan intim di antara dua kodrat di dalam diri Yesus Kristus (nature-perichoresis), Pribadi-Pribadi Allah Trinitas (personperichoresis), ${ }^{43}$ Allah dengan ciptaan (reality-perichoresis), ${ }^{44}$ dan

40. Lihat Pranoto, Perikhoresis Sabda-Roh, 92-96.

41. Lihat Jürgen Moltmann, "Perichoresis: An Old Magic Word for a New Trinitarian Theology", dalam Trinity, Community and Power: Mapping Trajectories in Wesleyan Theology, ed. M. Douglas Meeks (Nashville: Kingswood Books, 2000).

42. Michael G. Lawler, "Perichoresis: New Theological Wine in an Old Theological Wineskin", Horizons 22/1 (1988): 49-66.

43. Lawler, "Perichoresis", 49.

44. Lihat Joas Adiprasetya, An Imaginative Glimpse: The Trinity and Multiple Religious Participations (Eugene, OR: Pickwick, 2013), 1. 
perikhoresis Sabda-Roh (Word-Spirit Perichoresis). ${ }^{45}$ Tujuan utama persekutuan intim tersebut adalah untuk saling memberi diri dan relasi yang saling memenetrasi satu dengan lainnya. ${ }^{46}$ Dalam konteks pengertian person-perichoresis, Moltmann menambahkan bahwa:

Through their mutual indwelling the divine persons are giving each other themselves and the divine life in selfless love. The perichoretic community can also be seen as a kenotik community: The person are "emptying" themselves into one another. What the Son is doing by becoming human, according to Philippians 2:6, is nothing other than what he is doing in eternity with regard to the Father and the Spirit: giving oneself. ${ }^{47}$

Bagi Moltmann, komunitas perikhoresis adalah komunitas yang terbuka, mengundang, menyatukan dan mengintegrasikan ciptaan di dalam diri Allah (Yoh. 17:21).$^{48}$ Leonardo Boff menegaskan bahwa ide mengenai komunitas perikhoresis ini dapat memberikan pendorong bagi praksis transformasional pelayanan Kristen dalam konteks perjuangan pembebasan (liberation) melawan penindasan (oppression). Boff menegaskan:

45. Lihat Pranoto, Perikhoresis Sabda-Roh. Pranoto menginjeksi istilah ini untuk mengembangkan teologi tentang Kepemimpinan Feminis. Gagasannya diambil dari teologi "Dua Tangan Allah" dari Irenaeus. Lihat juga John Saward, The Scandal of the Incarnation, Irenaeus Against the Heresies (San Francisco: Ignatius Press, 1990), 31-32.

46. Miroslav Volf, Exclusion \& Embrace: A Theological Exploration of Identity, Otherness, and Reconciliation (Nashville: Abingdon Press, 1996), 181.

47. Moltmann, "Perichoresis: New Theological Wine", 115.

48 Moltmann, "Perichoresis: New Theological Wine”, 117. 
This understanding of the mystery of the Trinity is extremely rich in suggestion in the context of oppression and desire for liberation. The oppressed struggle for participation at all levels of life, for a just and egalitarian sharing while respecting the differences between persons and groups; they seek communion with other cultures and other values, and with God as the ultimately meaning of history and of their own hearts. ${ }^{49}$

Lebih lanjut Boff menambahkan bahwa komunitas perikhoresis dapat menjadi "the prototype of the human community dreamed of by those wish to improve society and build it in such a way as to make it into the image and likeness of the Trinity." ${ }^{50}$ Dalam konteks nature-perichoresis, Maximus Sang Pengaku menegaskan bahwa: kesatuan hypostasis Yesus Kristus berbicara mengenai tindakan Allah yang merengkuh ciptaan atau, yang disebut Hans Urs Von Balthasar, cosmic liturgy. ${ }^{51}$ Pranoto menulis: "Kesatuan hypostasis tersebut merupakan dasar bagi kesatuan sintesis antara Yang tak tercipta dan yang tercipta." ${ }^{52}$ Allah merengkuh ciptaan berarti "semua ciptaan Allah berharga, bernilai, dikasihi-Nya, serta sedang berarak-arakan menuju kepada Allah yang adalah pusatnya. ${ }^{\prime 53}$ Doktrin ini dapat membawa implikasi bahwa iman Kristen mesti menaruh perhatian dalam praksis transformasional pelayanan Kristen terhadap masalah penyembuhan krisis ekologi. Dalam konteks reality-perichoresis, Joas Adiprasetya menjelaskan pengertian mengenai

49. Leonardo Boff, Trinity and Society (Maryknoll: Orbis Books, 1988), 6. 50. Boff, Trinity and Society, 6.

51. Lihat, Hans Urs von Balthasar, Cosmic Liturgy: The Universe According to Maximus the Confessor (San Francisco: A Communio Book, 2003).

52. Pranoto, Perikhoresis Sabda-Roh, 29.

53. Pranoto, Perikhoresis Sabda-Roh, 29. 
"God's cosmological embrace of the world that it makes possible for the world to participate in the inner life of God" ${ }^{\prime 54}$ dan menurutnya ini dapat berimplikasi terhadap cara melihat secara imaginatif dan "mistik" tentang karya kehadiran Allah dalam konteks kehidupan bersama umat beragama. Adiprasetya mengatakan:

Perichoresis can answer the problem of unity and difference of multiple religion because of its ability to embrace creation without diminishing the diversity found in the world. In asserting the unity and difference within God's Triune life, perichoresis also highlight the way in which the whole creation can participate freely in the perichoretic life of the Triune God. ${ }^{55}$

Dalam konteks Word-Spirit perichoresis, Minggus M. Pranoto melihat pentingnya keadilan untuk menilai dan menghargai karya Yesus Kristus dan Roh Kudus sebagai sama-sama penting dan setara untuk dijadikan landasan bagi perjuangan kepemimpinan feminis. Terlalu menekankan karya Yesus Kristus menyebabkan gereja bercorak patriarki dan akibatnya menutup peluang adanya perempuan pemimpin; sebaliknya penekanan berat sebelah pada karya Roh Kudus menyebabkan gereja berfokus pada karunia-karunia rohani saja dengan melupakan perjuangan sosial (termasuk keberpihakan kepada perempuan yang termarjinal) sebagaimana yang dilakukan oleh Yesus Kristus. ${ }^{56}$

Penjelasan sepintas dari berbagai konsep perikhoresis dan praksis transformasional pelayanan Kristen di atas menunjukkan bahwa teologi

54. Adiprasetya, An Imaginative Glimpse, 1.

55. Adiprasetya, An Imaginative Glimpse, 158.

56. Pranoto, Perikhoresis Sabda-Roh, 194-97. 
Patristik masih relevan dan membuktikan adanya kegairahan kembali atas kebangkitan teologi Patristik dalam diskursus teologi Kristen kontemporer. Teologi Patristik tidak berfokus pada isu-isu kosmologi atau terkait dengan kompleksitas persoalan manusia dan ciptaan lainnya saja, tetapi juga berfokus penekanannya pada aspek soteriologi. Kebangkitan studi teologi Patristik (contoh perikhoresis Trinitaris) akan berbahaya jika mengabaikan pengakuan iman Kristen yang terkait penebusan dan keselamatan Allah Trinitas. ${ }^{57}$ Teologi Patristik setia terhadap kerygma rasul-rasul dan tujuannya agar kehidupan orang percaya memuliakan Allah dan berjuang untuk melakukan praksis transformasional pelayanan Kristen.

\section{Daftar Pustaka}

Adiprasetya, Joas. An Imaginative Glimpse: The Trinity and Multiple Religious Participations. Eugene: Pickwick, 2013.

Balthasar, Hans Urs Von. Cosmic Liturgy: The Universe According to Maximus the Confessor. San Francisco: A Communio Book, 2003.

Boff, Leonardo. Trinity and Society. Maryknoll: Orbis Books, 1988.

Bradshaw, David. "The Concept of The Divine Energies". Dalam Philosophy \& Theology 18/1 (2000): 93-120.

Florovsky, George. "St. Gregory Palamas and the Tradition of the Fathers" Dalam The Collected Works of Georges Florovsky. Vaduz, Europa: Buchervertriebsanstalt, 1987. ."The Authority of the Ancient Councils and the Tradition of the Fathers" Dalam Eastern Orthodox Theology: A

57. Keith E. Johnson, "Foreword", dalam Keith E. Johnson, Rethinking The Trinity \& Religious Pluralism: An Augustinian Assessment (Downers Grove, IL: IVP Academic, 2011), $9,10$. 
Contemporary Reader. Disunting oleh Daniel B. Clendenin Grand Rapids: Baker Academic, 2003.

."The Function of The Tradition in the Ancient Church".

Dalam Eastern Orthodox Theology: A Contemporary Reader.

Disunting oleh Daniel B. Clendenin. Grand Rapids, MI: Baker Academic, 2003.

Goode, William. Divine Rule of Faith and Practice, Vol. II. London: J. Hatchard and Son, 1842.

Kant, Immanuel Kant. The Conflict of the Faculties. Diterjemahkan oleh Mary J. Gregor. New York: Abaris Books, 1979.

LaCugna, Catherine Mowry. God For Us: The Trinity \& Christian Life. Chicago: HarperCollins, 1993.

McGrath, Alister E. Historical Theology: An Introduction to the History of Christian Thought. Malden: Blackwell, 1998.

Moltmann, Jürgen. "Perichoresis: An old Magic Word for a New Trinitarian Theology" Dalam Trinity, Community and Power: Mapping Trajectories in Wesleyan Theology, Diedit oleh M. Douglas Meeks (Nashville: Kingswood Books, 2000).

Nesteruk, Alexei. The Universe as Communion: Towards a NeoPatristic Synthesis of Theology and Science. London: T. \& T.Clark, 2008.

Olson, Roger E. Olson. The Story of Christian Theology: Twenty Centuries of Tradition \& Reform. Downers Grove: InterVarsity Press, 1999.

Pranoto, Minggus M. Perikhoresis Sabda-Roh: Imajinasi "Dua Tangan Allah" untuk Kepemimpinan Feminis. Ungaran: STT Abdiel dan Semarang: Elsa Press, 2018.

Prestige, George L. Fathers and Heretics. New York: The Macmillan, 1940.

Saward, John. The Scandal of The Incarnation, Irenaeus Against The Heresies. San Francisco: Ignatius Press, 1990.

Tollefsen, Torstein. The Christocentric Cosmology of St. Maximus the Confessor. Oxford: Oxford University Press, 2008.

Volf, Miroslav. Exclusion \& Embrace: A Theological Exploration of Identity, Otherness, and Reconciliation. Nashville: Abingdon Press, 1996. 


\section{Jurnal}

Lawler, Michael G. "Perichoresis: New Theological Wine in an Old Theological Wineskin", Horizons 22/1 (1988): 49-66

\section{Internet}

http://www.vatican.va/archive/hist_councils/ii_vatican_council/doc uments/vatii_const_19651207_gaudium-et-spes_en.html. Diakses 17 Juli 2019. 